\title{
PERILAKU HIDUP BERSIH DAN SEHAT (PHBS) SISWA DI SDN 42 KORONG GADANG KECAMATAN KURANJI PADANG
}

\author{
CLEAN AND HEALTY LIVING BEHAVIOR (PHBS) STUDENTS IN PUBLIC \\ ELEMENTARY SCHOOLS 42 KORONG GADANG DISTRICT KURANJI PADANG
}

\author{
Henico Putri Lina \\ D-III Keperawatan Padang \\ Jurusan KeperawatanPoltekkes Kemenkes Padang \\ Email :henicoputri@gmail.com
}

\begin{abstract}
School is one of the educational institutions that serve as targets Behavior Clean and Healthy Lifestyle (PHBs). This is because the amount of data a disease that occurs in school-age children (ages 6-10) such as intestinal worms ( 60-80\%), and dental caries (74\%). This study aimsto describe of PHBS students at 42elementary school Korong Gadang Kuranji District of Padang in 2014. This research is descriptive. Thepopulation was all students grades 4-6 elementary school who are 71 and all the population sampled. Univariatble descriptive analysis to describe the characteristics of the respondent. The results showed that the knowledge was lowest for the use of sanitary latrines and healthier, which amounted to $67.6 \%$, amounting to $56.3 \%$ of students did not accept to be a healthy snack in the cafeteria sekolahdan as much as $100 \%$ of students do not carry healthy snacks in the school cafeteria. This study suggests that schools can optimize the PHBs by activating the UKS program at the school. This study suggests that schools can optimize the PHBs by activating the program of School Health Unit
\end{abstract}

Keywords: behavio-r, students, 42 Elementary School Korong Gadang

\begin{abstract}
Abstrak: Sekolah adalah salah satu institusi pendidikan yang dijadikan sebagai sasaran PHBS. Hal ini dikarenakan banyaknya data penyakit yang terjadi pada anak usia sekolah (usia 6-10) seperti cacingan (60-80\%), dan karies gigi (74\%). Penelitian ini bertujuan untuk mengetahui gambaran PHBS siswa di SDN 42 Korong Gadang Kecamatan Kuranji Padang tahun 2014. Jenis penilitian ini adalah deskriptif. Populasi penelitian adalah seluruh siswa kelas 4-6 SD yang berjumlah 71 orang dan semua populasi dijadikan sampel. Analisis data menggunakan deskriptif univariabel untuk mendeskripsikan karakteristik responden. Hasil penelitian menunjukkan bahwa pengetahuan terendah terdapat pada penggunaan jamban bersih dan sehat, yaitu sebesar $67,6 \%$, sebesar $56,3 \%$ siswa bersikap tidak menerima untuk jajan sehat di kantin sekolahdan sebanyak $100 \%$ siswa tidak melaksanakan jajan sehat di kantin sekolah. Penelitian ini menyarankan agar sekolah dapat mengoptimalkan PHBS dengan mengaktifkan program UKS di sekolah.
\end{abstract}

Kata kunci: perilaku, siswa, SDN 42 Korong Gadang

\section{PENDAHULUAN}

WHO menyatakan sehat adalah salah satu hak dari individu untuk dapat melaksanakan segala bentuk kegiatan atau rutinitas sehari-hari. Agar hidup sehat dapat terlaksana, maka setiap orang harus mampu memiliki perilaku yang baik, yaitu Perilaku Hidup Bersih dan sehat. PHBS merupakan strategi yang digunakan untuk menciptakan kemandirian dalam menciptakan dan meraih kesehatan dan merupakan suatu perilaku yang diterapkan berdasarkan kesadaran yang merupakan hasil dari pembelajaran yang dapat membuat individu atau anggota keluarga bisa meningkatkan taraf kesehatannya di bidang kesehatan masyarakat (Dekes RI, 2010).

PHBS adalah salah satu esensi dan hak asasi manusia untuk tetap mempertahankan kelangsungan hidupnya. Hal ini selaras dengan yang tercakup dalam konstitusi WHO tahun 1948. WHO dalam Maryunani, dkk (2012), menyatakan bahwa derajat kesehatan yang tinggi merupakan hak yang 
mendasar bagi individu. Hak ini berlaku bagi semua orang tanpa membedakan asal-usul, agama, ras, politik dan tingkat ekonomi. Derajat kesehatan yang tinggi tersebut dapat diperoleh apabila setiap orang memiliki perilaku yang memperhatikan kesehatan.

Konsep perilaku yang dikembangkan Becker, merupakan konsep yang didasarkan pada konsep perilaku sehat Bloom. Becker menjabarkan bahwa perilaku sehat tersebut terbagi menjadi tiga domain, yaitu pengetahuan terhadap kesehatan (health knowledge), sikap untuk merespon tindakan kesehatan (health attitude) dan praktik atau tindakan kesehatan (health practice). Domain ini bermanfaat untuk mengetahui seberapa besar tingkat perilaku sehat setiap individu (Notoatmodjo, 2010).

Becker membagi perilaku sehat menjadi tiga bagian pertama, pengetahuan tentang kesehatan, yaitu apa saja yang diketahui oleh individu tentang cara meningkatkan dan memelihara kesehatan. Kedua, sikap untuk merespon tindakan kesehatan, yaitu penilaian individu atas hal-hal yang berhubungan dengan cara memelihara kesehatan. Ketiga, praktik atau tindakan kesehatan yang merupakan tindakan langsung yang terdiri dari semua kegiatan untuk memperoleh kehidupan yang sehat. (Notoatmodjo, 2010).

Berdasarkan visi Indonesia sehat 2010, terdapat paradiga sehat yang terdiri dari tiga pilar, yaitu lingkungan sehat, perilaku sehat dan pelayanan kesehatan yang bermutu, adil dan merata. Perilaku sehat ini merupakan perilaku yang digunakan untuk memelihara , meningkatkan kesehatan, menghindari atau mencegah terjadinya penyakit, melindungi diri dari berbagai macam penyakit, dan keikutsertaan dalam meningkatkan kualitas kesehatan (Depkes RI, 2013). Program perbaikan tidak hanya sebatas pada lingkungan sehat dan pelayanan kesehatan, tetapi juga memperhatikan faktor perilaku, hal ini disebabkan faktor perilaku dapat menjadi faktor terjadinya berbagai penyakit, baik penyakit menular maupun penyakit tidak menular (Marlina, 2011).

Kualitas dari setiap sumber daya manusia (SDM) ditentukan oleh dua faktor yang saling berhubungan dan berkaitan. Faktor tersebut terdiri dari pendidikan dan kesehatan. Kesehatan adalah syarat utama dalam memperoleh keberhasilan upaya pendidikan, sedangkan pendidikan merupakan salah satu faktor untuk tercapainya status kesehatan yang tinggi dari setiap individu (Maryunani, dkk, 2012).

Untuk menciptakan SDM yang berkualitas dan mampu bersaing, perlu adanya tindakan pengawasan terhadap kesehatan. Pengawasan tersebut dapat dimulai dari usia dini, yaitu usia anak sekolah. Mulai dari tingkat pra sekolah, SD, SMP, dan SMA. Pada usia ini, anak akan belajar langsung dari lingkungannya. Lingkungan disini dapat diartikan sebagai orang tua, guru, dan teman sepermainan. Mereka dapat mempelajari bagaimana harus bertingkah laku yang sesuai dan tidak sesuai dengan aturan.

Program PHBS dapat dikelompokkan kedalam 5 tatanan lingkungan kehidupan, yaitu PHBS di lingkungan sekolah, PHBS di lingkungan rumah tangga, PHBS di lingkungan institusi kesehatan, PHBS di lingkungan tempat umum, dan PHBS di lingkungan tempat kerja (Maryunani, dkk, 2012). PHBS di lingkungan sekolah mempunyai delapan indikator, yaitu mencuci tangan menggunakan air mengalir dan memakai sabun, mengkonsumsi jajanan sehat di kantin sekolah, menggunakan fasilitas jamban bersih dan sehat, melaksanakan olahraga secara teratur, memberantas jentik nyamuk di sekolah, tidak merokok di lingkungan sekolah, mengkur berat badan dan tinggi badan, serta membuang sampah pada tempat yang telah disediakan. Kedelapan indikator ini harus dilakukan dengan baik agar tercipta perilaku sehat di lingkungan sekolah.

Sekolah merupakan institusi pendidikan yang menjadi target PHBS, sehingga penerapan perilaku tersebut menjadi lebih baik. Hal ini disebabkan karena terdapatnya banyak data yang menampilkan bahwa sebagian besar penyakit yang sering diderita anak usia sekolah (usia 6-10) ternyata berkaitan dengan PHBS. Selain itu, masih kurangnya pelaksanaan PHBS di lingkungan sekolah dapat menyebabkan dampak lain, yaitu kurang nyamannya suasana belajar akibat lingkungan kelas yang kotor, menurunnya prestasi dan semangat belajar 
siswa, serta dapat membuat citra sekolah menjadi buruk. Oleh sebab itu, sangat perlu pemberian pemahaman tentang nilainilai PHBS sejak dini di sekolah melalui program Usaha Kesehatan sekolah (UKS) (Proverawati, dkk, 2012).

UKS adalah bagian dari program kesehatan anak usia sekolah. Kegiatan ini merupakan salah satu upaya terpadu antara lintas program dan lintas sektor. UKS dapat dijadikan sebagai tempat pelaksanaan pendidikan dan kesehatan secara bersamaan, terencana dan bertanggung jawab dalam menciptakan, mengembangkan serta melaksanakan kegiatan hidup bersih dan sehat. Kegiatan ini dapat dilakukan oleh siswa, guru, dan masyarakat lingkungan sekolah (Depkes RI, 2010).

Pembinaan PHBS di sekolah dapat diberikan pada tiga kelompok sasaran PHBS, sasaran primer, sasaran sekunder, dan sasaran tersier. Sasaran primer pada pembinaan PHBS di sekolah adalah siswa $\mathrm{SD}$, dimana mereka diharapkan dapat untuk mengetahui dan melaksanakan PHBS. Sasarn sekunder adalah orang-orang yang mempunyai pengaruh pada sasaran primer dalam mengambil keputusan untuk melaksanakan PHBS. Pada PHBS di sekolah yang menjadi sasaran sekunder adalah guru, dimana seorang guru adalah panutan dari para siswa. Sasaran tersier adalah orang yang berfungsi untuk mengambil keputusan formal, seperti komite sekolah, kepala desa, lurah, camat, dinas pendidikan, puskesmas dan sebagainya. Mereka dapat memberikan dukungan dalam menentukan kebijakan, pendanaan dalam proses Pembinaan PHBS yang akan diberikan kepada siswa sekolah (Pedoman Pembinaan PHBS Kemenkes RI, 2011).

Undang-Undang RI No.36 tahun 2009 bab VI pasal 79 Ayat, tentang Upaya Kesehatan menjelaskan bahwa upaya pembinaan kesehatan di lingkungan sekolah diselenggarakan dengan tujuan untuk meningkatkan dan mengembangkan kemampuan hidup yang lebih sehat oleh siswa. Kemampuan tersebut harus diterapkan dalam lingkungan kehidupan yang sehat, sehingga anak usia sekolah dapat belajar, tumbuh, berkembang dan memperoleh derajat kesehatan setinggi- tingginya agar menjadi SDM yang berkualitas.

Menurut WHO, sebanyak 100.000 anak Indonesia meninggal dunia karena penyakit diare setiap tahunnya, sedangkan data Departemen Kesehatan menunjukkan bahwa dari 1.000 penduduk, terdapat sebanyak 300 orang yang menderita penyakit diare sepanjang tahun (Profil Kesehatan Indonesia Tahun 2011). Selain itu juga masih terdapat sebanyak $40-60 \%$ anak usia sekolah yang menderita penyakit cacingan (Lubis, 2013).

Profil Kesehatan Indonesia tahun 2009 menyajikan data bahwa, terdapat sebanyak $64,41 \%$ sarana yang telah dibina lingkungannya untuk menerapkan kehidupan bersih dan sehat. Sarana tersebut terdiri dari institusi pendidikan sebanyak $67,52 \%$, tempat kerja sebanyak $59,15 \%$, dan lingkungan lainnya sebanyak $62,26 \%$ (Depker RI, 2010). Kehidupan bersih dan sehat di tatanan pendidikan, lingkungan tempat kerja, dan lingkungan fasilitas kesehatan belum berjalan sesuai dengan yang diinginkan, oleh sebab itu diperlukan pendekatan yang peripurna (komprehensif), lintas program dan lintas sektor, serta mobilisasi sumber daya yang luar biasa di semua tingkat administrasi pemerintah (Syukriyah, 2011).

Laporan Riset Kesehatan Dasar (Riskesdas) Nasional tahun 2013 menyatakan bahwa, kesehatan dipengaruhi oleh perilaku yang mejunjung tinggi keadaan kebersihan. Akibat kurangnya perhatian terhadap kebersihan ini, maka masih banyak penyakit yang timbul seperti diare, kecacingan, filariasis, demam berdarah dan muntaber. Masalah kebersihan yang masih banyak dialami oleh siswa SD yaitu, masalah pada gigi sebanyak $86 \%$, tidak bisa potong kuku sebanyak $53 \%$, tidak bisa menggosok gigi sebanyak $42 \%$ dan tidak mencuci tangan sebelum makan sebanyak $8 \%$. Sedangkan penyakit yang banyak diderita oleh siswa SD yaitu penyakit cacingan sebesar $60-80 \%$, dan caries gigi sebanyak $74,4 \%$. Oleh sebab itu, untuk mengatasi masalah tersebut perlu adanya upaya secara komprehensif dari berbagai sektor (Kementrian Kesehatan RI, 2013).

Penelitian Diva (2013), tentang gambaran perilaku hidup bersih dan sehat 
di SDN 29 Ulak Karang Padang didapatkan, bahwa pengetahuan siswa tentang PHBS masih rendah yaitu $53,35 \%$, sikap siswa yang negatif terhadap PHBS sebesar $40 \%$ dan 46,7\% siswa belum mampu bertindak sesuai indikator PHBS dengan baik. Menurut data Dinas Kesehatan Kota Padang tahun 2012, wilayah kerja Puskesmas yang memiliki presentase rumah tangga berPHBS tinggi adalah Puskesmas Ambacang sebesar 73,3\%, sedangkan wilayah kerja Puskesmas yang memiliki presentase rumah tangga ber-PHBS rendah adalah Puskesmas Kuranji dengan presentase sebesar 7,1\% (DKK Padang, 2012). Kurangnya PHBS pada tatanan rumah tangga di wilayah kuranji dapat mempengaruhi PHBS anakanak yang ada dalam lingkungan keluarga, sehingga akan dapat mempengaruhi perilaku anak-anak disekolah.

Berdasarkan data yang diperoleh dari Puskesmas Kuranji, Puskesmas ini membina program UKS di semua SDN yang termasuk ke dalam wilayah kerja. Salah satu SD yang dibiana yaitu SDN 42 Korong Gadang. Studi awal dilakukan melalui observasi dan wawancara. Dari informasi yang di didapatkan dari kepala sekolah SDN 42 Korong Gadang pada tanggal 22 Januari 2014, SDN tersebut tidak mempunyai kantin sekolah sehingga semua siswa jajan di luar sekolah. Untuk tempat mencuci tangan, siswa hanya mencuci tangan di kamar mandi, hal ini disebabkan karena belum adanya fasilitas untuk mencuci tangan. Untuk kegiatan olahraga, sekolah memiliki jadwal pelajaran penjaskes sekali seminggu dan senam pagi 3 kali seminggu yang dilaksanakan pada hari Selasa, Rabu dan Kamis. Kegiatan gotong-royong dan memberantas jentik jamuk, sekolah tidak mempunyai jadwal yang khusus. Dari 10 siswa yang diwawancarai, terdapat 5 siswa yang menyatakan tidak mencuci tangan sebelum makan dan jajanan di sekolah. Selain itu terdapat 4 orang siswa yang tidak menyiram toilet setelah $\mathrm{BAB} / \mathrm{BAK}$. Untuk kebiasaan membuang sampah, masih terlihat siswa yang membuang sampah tidak pada tempat yang telah disediakan oleh pihak sekolah. Berdasarkan data tersebut, perlu dilakukannya upaya untuk untuk mengetahui tentang pengetahuan, sikap, dan tindakan siswa tentang PHBS di SDN 42 Korong Gadang Kecamatan Kuranji Padang.

\section{METODE}

Penelitian ini merupakan penelitian deskriptif yang digunakan untuk mendeskripsikan mengenai perilaku siswa tentang PHBS. Penelitian ini dilakukan di SDN 42 Korong Gadang Kecamatan Kuranji Padang tanggal 22 Maret 2014. Populasi dalam penelitian ini adalah siswa kelas 4, 5 dan 6 SDN 42 Korong Gadang yang berjumlah 71 orang (kelas 4 sebanyak 22 orang, kelas 5 sebanyak 31 orang dan kelas 6 sebanyak 18 orang). Jumlah sampel pada penelitian ini menggunakan total populasi, sehinga jumlah sampel adalah 71 orang. Kriteria menjadi sampel adalah bersedia menjadi responden, serta merupakan murid kelas 4, 5 dan 6 SDN 42 Korong Gadang Kecamatan Kuranji dan berada ditempat atau hadir waktu diadakan penelitian. Pada penelitian ini penulis mengambil sampel kelas 4, 5 dan 6, tidak pada kelas 1, 2 dan 3, karena kelas 1, 2 dan 3 kemungkinan belum memenuhi kriteria mampu membaca dan menulis serta kemungkinan belum paham dan mengerti terhadap pertanyaan yang disampaikan.

Variabel dalam penelitian ini adalah perilaku yang terdiri dari pengetahuan tentang PHBS, sikap terhadap PHBS, dan tindakan PHBS siswa di sekolah. Instrumen yang digunakan untuk pengumpulan data masing-masing variabel adalah kuisioner. Kuesioner tersebut telah diuji reabilitas dan validitasnya.

Kuisioner terdiri dari 55 pertanyaan dalam bentuk pilihan ganda dan check list. Untuk variabel pengetahuan berupa pilihan ganda (multiple choise), sedangkan untuk pertanyaan sikap menggunakan scale ritchket dan untuk tindakan menggunakan check list.

Scoring dalam penelitian ini dilakukan dengan memberikan kode untuk masingmasing variable. Pada variabel pengetahuan , apabila jawaban benar diberi nilai 1 , jika 
jawaban salah diberi nilai 0 . Variable sikap terdiri dari 4 skala yaitu sangat tidak setuju diberi nilai 1, tidak setuju diberi nilai 2 , setuju diberi nilai 3 , dan sangat setuju diberi nilai 4. Variable tindakan terbagi menjadi 2 pernyataan yaitu, Ya diberi nilai 1 , Tidak diberi nilai 0

Analisa data yang digunakan untuk tingkat pengetahuan terbagi tiga yaitu tinggi bila hasil yang didapatkan $\geq 76-100 \%$, sedang bila hasil yang didapatkan $56-75 \%$, rendah bila hasil yang didapatkan $<56 \%$. Variable sikap terdiri dari 2 kategori yaitu menerima dan tidak menerima. menerima bila hasil yang didapatkan $\geq$ mean, tidak menerima bila hasil yang didapatkan $<$ mean. Variabel tindakan teridiri dari 2 kategori yaitu baik dan kurang baik. Baik jika hasil yang didapatkan $\geq$ mean, kurang baik jika hasil yang didapatkan $<$ mean.

Setelah data kuesioner terkumpul, maka dilakukan pengolahan data dengan cara editing, coding, entry data, cleaning, tabulating, dan analisa data. Data yang

Tabel 1. Distribusi Frekuensi Karakteristik Responden Berdasarkan Usia

\begin{tabular}{lcc}
\hline Usia (tahun) & Frekuensi & Persentase (\%) \\
\hline $\mathbf{9}$ & 12 & 16.9 \\
$\mathbf{1 0}$ & 9 & 12.7 \\
$\mathbf{1 1}$ & 24 & 33.8 \\
$\mathbf{1 2}$ & 19 & 26.8 \\
$\mathbf{1 3}$ & 6 & 8.5 \\
$\mathbf{1 5}$ & 1 & 1.4 \\
\hline Jumlah & $\mathbf{7 1}$ & $\mathbf{1 0 0}$ \\
\hline
\end{tabular}

diperoleh atau dikumpulkan diperiksa kembali kelengkapannya, kemudian dilakukan pemberian kode angka pada kuesioner. Kemudian dilakukan pengecekan kembali apakah data yang telah dientri sudah benar atau masih ada kesalahan. Setelah semua data dibersihkan, maka data di tabulasikan dan kemudian akan dianalisa. Analisa data yang digunakan dalam penelitian ini adalah analisa univariabel yang bertujuan untuk menjelaskan karakteristik variabel pengetahuan, sikap, dan tindakan.

\section{HASIL PENELITIAN}

Setelah penelitian dan pengambilan data selesai dilakukan, maka diperoleh hasil data. Data yang diperoleh meliputi perilaku yang terdiri dari pengetahuan tentang PHBS , sikap terhadap PHBS dan tindakan PHBS siswa dengan menggunakan kuesioner.

Berdasarkan Tabel 1, diketahui bahwa usia responden yang terbanyak adalah usia anak kelas $5 \mathrm{SD}$, yaitu usia 11 tahun dengan presentase $33,8 \%$.

Tabel 3. Distribusi Frekuensi Karakteristik Responden Berdasarkan Tingkat Pengetahuan tentang PHBS

\begin{tabular}{lccccccccc}
\hline \multirow{2}{*}{ Tingkat Pengetahuan } & \multicolumn{2}{c}{ Tinggi } & \multicolumn{3}{c}{ Sedang } & \multicolumn{3}{c}{ Rendah } & \multicolumn{2}{c}{ Jumlah } \\
\cline { 2 - 9 } & $\sum$ & $\mathbf{\%}$ & $\sum$ & $\mathbf{\%}$ & $\sum$ & $\mathbf{\%}$ & $\sum$ & $\mathbf{\%}$ \\
\hline Cuci Tangan Denagan Air Mengalir dan & 44 & 62 & 25 & 35,2 & 2 & 2,8 & 71 & 100 \\
menggunakan Sabun & 14 & 19,7 & 23 & 32,4 & 34 & 47.9 & 71 & 100 \\
Jajan Sehat di Kantin Sekolah & 11 & 15,5 & 12 & 16,9 & 48 & 67,6 & 71 & 100 \\
Menggunakan Jamban Bersih dan sehat & 26 & 36,6 & 23 & 32,4 & 22 & 31 & 71 & 100 \\
Olahraga Secara Teratur & 26 & 36,6 & 20 & 28,2 & 25 & 35,2 & 71 & 100 \\
Memberantas Jentik Nyamuk di Sekolah & 7 & 9,9 & 21 & 29,6 & 43 & 60,6 & 71 & 100 \\
Tidak Merokok & 4 & 5,6 & 23 & 32,4 & 44 & 62 & 71 & 100 \\
Mengukur BB dan TB Secara Teratur & 42 & 59,2 & 5 & 7 & 24 & 33,8 & 71 & 100 \\
Membuang Sampah Pada Tempatnya & & & & & & &
\end{tabular}


Berdasarkan tabel 2, diketahui bahwa sebagian besar responden berjenis kelamin laki-laki dengan persentase 59,2 \%.

Berdasarkan tabel 3, diketahui bahwa sebagian besar responden masih memiliki pengetahuan yang rendah tentang indikator PHBS di sekolah, dimana pengetahuan yang paling rendah terdapat pada penggunaan jamban bersih dan sehat, yaitu sebanyak $67,6 \%$. Pengetahuan yang paling tinggi terdapat pada cuci tangan menggunakan air mengalir dan sabun sebanyak $62 \%$.

Berdasarkan tabel 4, diketahui bahwa sebanyak $63,4 \%$ responden menerima untuk menggunakan jamban bersih dan sehat serta membuang sampah pada tempatnya, dan $56,3 \%$ responden tidak menerima untuk jajan sehat di kantin sekolah.
Berdasarkan tabel 5, diketahui bahwa sebanyak $97,2 \%$ responden membuang sampah pada tempatnya dan $100 \%$ responden tidak jajan sehat di kantin sekolah.

\section{PEMBAHASAN}

\section{Karakteristik Responden Berdasarkan Umur Dan Jenis Kelamin}

Berdasarkan tabel 1, didapatkan hasil bahwa dari 71 responden kelas IV, V, dan VI terdapat sebanyak 24 orang $(33,8 \%)$ responden yang berumur 11 tahun dan juga terdapat responden yang memiliki umur paling tua yaitu 15 tahun sebanyak 1 orang $(1,4 \%)$. Anak pada usia sekolah

Tabel 4. Distribusi Frekuensi Karakteristik Responden Berdasarkan Sikap Terhadap PHBS

\begin{tabular}{lccccccc}
\hline \multirow{2}{*}{ Sikap } & \multicolumn{2}{c}{ Menerima } & \multicolumn{3}{c}{ Tidak Menerima } & \multicolumn{2}{c}{ Jumlah } \\
& $\sum$ & $\mathbf{\%}$ & $\sum$ & $\mathbf{\%}$ & $\sum$ & $\mathbf{\%}$ \\
\hline Cuci Tangan Denagan Air Mengalir dan & 36 & 50,7 & 35 & 49,3 & 71 & 100 \\
Menggunakan Sabun & 31 & 43,7 & 40 & 56,3 & 71 & 100 \\
Jajan Sehat di Kantin Sekolah & 45 & 63,4 & 26 & 36,6 & 71 & 100 \\
Menggunakan Jamban Bersih dan sehat & 40 & 56,3 & 31 & 43,7 & 71 & 100 \\
Olahraga Secara Teratur & 34 & 47,9 & 37 & 52,1 & 71 & 100 \\
Memberantas Jentik Nyamuk di Sekolah & 39 & 54,9 & 32 & 45,1 & 71 & 100 \\
Tidak Merokok & 33 & 46,5 & 38 & 53,5 & 71 & 100 \\
Mengukur BB dan TB Secara Teratur & 45 & 63,4 & 26 & 36,6 & 71 & 100 \\
Membuang Sampah Pada Tempatnya & & & & &
\end{tabular}

Tabel 5. Distribusi Frekuensi Karakteristik Responden Berdasarkan Tindakan PHBS Siswa

\begin{tabular}{lccccccc}
\hline \multirow{2}{*}{ Tindakan } & \multicolumn{2}{c}{ Melakukan } & \multicolumn{3}{c}{ Tidak Melakukan } & \multicolumn{2}{c}{ Jumlah } \\
& $\sum$ & $\mathbf{\%}$ & $\sum$ & $\mathbf{\%}$ & $\sum$ & $\mathbf{\%}$ \\
\hline Cuci Tangan Denagan Air Mengalir dan & 67 & 94.4 & 4 & 5,6 & 71 & 100 \\
Menggunakan Sabun & 0 & 0 & 71 & 100 & 71 & 100 \\
Jajan Sehat di Kantin Sekolah & 65 & 91,5 & 6 & 8,5 & 71 & 100 \\
Menggunakan Jamban Bersih dan sehat & 52 & 73,2 & 19 & 26,8 & 71 & 100 \\
Olahraga Secara Teratur & 31 & 43,7 & 40 & 56,3 & 71 & 100 \\
Memberantas Jentik Nyamuk di Sekolah & 45 & 63,4 & 26 & 36,6 & 71 & 100 \\
Tidak Merokok & 33 & 46,5 & 38 & 53,5 & 71 & 100 \\
Mengukur BB dan TB Secara Teratur & 69 & 97,2 & 2 & 2,8 & 71 & 100 \\
Membuang Sampah Pada Tempatnya & & & & & &
\end{tabular}


dasar, sangat penting untuk memperoleh pengawasan dari orang yang lebih tua darinya, termasuk dalam hal pengawasan kesehatan. Hal ini disebabkan karena pada sekolah dasar anak-anak berada pada tahap prose tumbuh kembang yang sangat pesat. Saat usia ini, anak akan sering mengalami dan menghadapi berbagai macam kondisi yang ada di lingkungannya yang dapat menjadi sumber munculnya berbagai macam penyakit (Zaviera, 2008).

Menurut teori Erikson, anak yang berada pada usia pra-sekolah merupakan anak yang berada pada fase inisiatif dan rasa bersalah. Pada tahap ini, rasa ingin tahu dan daya imaginasi anak berkembang, oleh sebab itu anak akan banyak mempunyai pertanyaan tentang berbagai hal di lingkungannya yang tidak dia ketahui. Pada usia ini anak juga akan mencoba untuk meniru tingkah laku atau perilaku orang dewasa yang ada disekitarnya (Nursalam, 2008).

Berdasarkan tabel 2, didapatkan hasil penelitian, dimana terdapat sebanyak 42 orang $(59,2 \%)$ responden berjenis kelamin laki-laki, sedangkan siswa berjenis kelamin perempuan sebanyak 29 orang $(40,8 \%)$. Siswa laki-laki maupun siswa perempuan mempunyai hak yang sama untuk melakukan perilaku sehat, hal ini dikarenakan PHBS tersebut berlaku bagi semua orang untuk meningkatkan kesehatannya. Hal ini sesuai dengan penelitian yang dilakukan oleh Utami (2009) di SDN 013 Sunter Agung Jakarta Utara, yang menyatakan bahwa tidak ada hubungan antara jenis kelamin dengan penerapan PHBS.

\section{Pengetahuan}

Berdasarkan tabel 3, diketahui bahwa masih terdapat responden yang masih berpengetahuan rendah tentang PHBS di sekolah. Pengetahuan terendah terdapat pada penggunaan jamban bersih dan sehat, pengukuran $\mathrm{BB}$ dan $\mathrm{TB}$ secara teratur, dan tidak merokok di sekolah. Pengetahuan tertinggi terdapat pada indikator mencuci tangan menggunakan air mengalir dan memakai sabun.

Pengetahuan penggunaan jamban bersih dan sehat harus diberikan kepada siswa, hal ini bertujuan agar lingkungan di sekolah tetap bersih, sehat, dan tidak mencemari sumber air yang ada di sekitarnya. Selain itu juga dapat menghindari datangnya organisme yang dapat menjadi penyebab penularan penyakit. Pengetahuan mengukur BB dan TB secara teratur juga harus diberikan kepada siswa, sehingga mereka tahu bahwa mengukur berat badan dan tinggi badan dilakukan setiap bulan. Mereka harus diberikan pemahaman, bahwa kegiatan ini bertujuan untuk mengetahui tumbuh kembang dan deteksi dini terhadap kekurangan atau kelebihan gizi. Pengetahuan merokok sangat penting diberikan kepada siswa, hal ini disebabkan karena rokok mengandung zat-zat kimia yang dapat membahayakan kesehatan. Seluruh masyarakat yang ada di lingkungan sekolah tidak diperbolehkan untuk merokok. Keinginan merokok ini timbul karena siswa mencontoh perilaku yang ada di lingkungannya dan mereka beranggapan bahwa merokok sebagai lambing kedewasaan. (Pusat Promkes Depkes RI).

Pengetahuan merupakan hasil tahu setiap individu terhadap objek yang didapatkannya melalui alat indra yang dimilki. Dari hasil indra tersebut, individu dapat menghasilkan pengetahuan yang dipengaruhi oleh seberapa sering individu tersebut memperhatikan suatu objek (Notoatmodjo, 2010).

Pengetahuan yang cukup dalam kognitif mempunyai 6 tingkat, yaitu tahu (Know), memahami (Comprehension), aplikasi (Aplication), analisis (Analysis), sintesis (Synthesis), dan evaluasi (Evaluation) (Notoatmodjo, 2013). Tahu merupakan daya ingat terhadap sesuatu yang telah dipelajari atau mengingat kembali (recall). Tahu merupakan bagian dari pengetahuan yang paling rendah. Memahami merupakan kemampuan untuk menjelaskan kembali tentang apa yang telah diketahui dan dapat diinterpretasikan. Aplikasi merupakan bagaimana seseorang menerapkan sesuatu yang telah diketahui dan dipahaminya dalam kehidupan sehari-hari.

Analisis merupakan kemampuan seseorang dalam menjabarkan suatu hal kemudian mencari hubungan antara suatu hal yang telah diketahui, sehingga ia dapat membedakan, mengelompokkan 
bagian-bagian hal tersebut. Sintesis adalah kemampuan untuk menghubungkan bagian dari suatu objek yang telah ada menjadi suatu hal yang baru, atau kemampuan untuk menyusun rumusan baru dari rumusanrumusan yang telah ada sebelumnya, dan evaluasi merupakan kemampuan melakukan penilaian terhadap suatu objek. Penilaian tersebut dilaksanakan berdasarkan kriteria yang telah ada.

Teori Green menjelaskan bahwa suatu perilaku ditentukan oleh factor predisposisi (predisposing factors). Factor-faktor ini digunakan untuk mempermudah seseorang untuk berperilaku, misalnya pengetahuan, sikap, keyakinan, adat istiadat, tradisi, dan sebagainya. untuk dapat menerapkan PHBS di lingkungan sekolah, maka perlu diberikannya pengetahuan tentang perilaku tersebut. Dengan pemberian pengetahuan ini, diharapkan dapat membentuk sikap siswa tentang kehidupan yang sehat, sehingga hal tersebut dapat diterapkan menjadi suatu kebiasaan untuk berperilaku bersih dan sehat di sekolah (Mulyadi, 2014).

Penelitian yang dilakukan oleh Elfi Syukriah (2011), tentang PHBS di SDN 06 Lubuk Layang, didapatkan hasil sebanyak $47,5 \%$ siswa juga masih memiliki pengetahuan yang kurang tentang PHBS. Terdapatnya siswa yang masih kurang pengetahuaannya tentang PHBS dapat disebabkan oleh berbagai faktor, diantaranya pihak sekolah maupun petugas kesehatan yang belum efektif memberikan informasi dan pembinaan tentang PHBS, sehingga informasi tersebut masih kurang dipahami oleh siswa. Untuk meningkatkan tingkat pengetahuan siswa, perlu adanya bimbingan dan arahan yang diberikan oleh guru ataupun tenaga kesehatan secara terusmenerus dan memberikan pendidikan dan pemberdayaan kesehatan secara khusus melalui UKS dan pembentukan dokter kecil untuk meningkatkan pengetahuan dan pemahaman siswa tentang PHBS dan dengan sendirinya mereka akan memahami dan menyadari pentingnya untuk berperilaku bersih dan sehat.

Pembiaan PHBS merupakan salah satu upaya yang dilakukan untuk menciptakan dan membiasakan perilaku hidup yang berorientasi pada kebersihan dan kesehatan di lingkungan masyarakat, sehingga mereka dapat mencegah berbagai penyakit dan dapat meningkatkan kualitas hidup yang sehat. Pembinaan PHBS diselenggarakan melalui promosi kesehatan, yaitu upaya membantu individu maupun masyarkat agar tahu, mau dan mampu melaksanakan dan mempraktekkan PHBS. Upaya promosi kesehatan dapat melalui proses pembelajaran untuk mencegah dan menanggulangi masalah kesehatan yang ada (Pedoman Pembinaan PHBS Kemenkes RI, 2011).

Pemperdayaan dalam promosi kesehatan adalah hal yang sangat penting. Pemberdayaan ini merupakan proses agar masyarakat sekolah dapat berperan dalam pengambilan dan penetapan tindakan yang berhubungan dengan kualitas kesehatannya. Pemberdayaan merupakan tindakan pemberian informasi pada kelompok sasaran secara terus-menerus, memperhatikan perkembangan sasaran, serta membantu mengubah dari tidak tahu menjadi tahu (aspek knowledge), dari tahu menjadi mau (aspek attitude), dan dari mau menjadi mampu untuk melaksanakan dan mempraktekan perilaku yang telah diberikan atau diperkenalkan (aspek practice).

Upaya yang dilakukan agar siswa menjadi tahu adalah dengan cara membuat siswa tersebut memahami hal yang dapat menjadi masalah baginya dan orangorang di sekitarnya. Apabila siswa belum mengetahui dan menyadari sesuatu sebagai masalah, maka ia tidak akan bersedia menerima informasi apapun. Perubahan dari tahu ke mau harus dengan menyajikan dan menampilkan fakta-fakta tentang masalah tersebut (Pedoman Pembinaan PHBS Kemenkes RI, 2011).

Masa anak-anak ini sangat tepat untuk menanamkan nilai-nilai positif dan kesehatan, sehingga dapat terbiasa dan terbawa sampai usia dewasa nantinya. Diawali dengan memberikan pengertian tentang PHBS dan dilanjutkan dengan halhal mengenai kesehatan lainnya, maka diharapkan akan tumbuh minat dan kemauan dari siswa untuk ikut dan aktif dalam menerapkan program PHBS. Apabila hal ini terlaksana, maka tujuan yang diharapkan akan tercapai dan pengetahuan siswa tentang PHBS akan lebih meningkat. 


\section{Sikap}

Berdasarkan tabel 4, diketahui bahwa terdapat responden yang masih belum mau menerima terhadap PHBS di sekolah. Sikap negatif siswa terdapat pada jajan sehat di kantin sekolah, pengukuran $\mathrm{BB}$ dan $\mathrm{TB}$ secara teratur, dan memberantas jentik nyamuk di sekolah. Indikator yang paling banyak diterima siswa adalah membuang sampah pada tempatnya.

Mengkonsumsi jajanan sehat di kantin sekolah merupakan suatu kebiasaan yang harus ditanamkan pada siswa. Hal ini sebagai upaya agar siswa terhindar dari kandungan zat kimia yang terdapat pada makanan yang dijual bebas di luar kantin sekolah. Makanan yang ada dikantin sekolah juga harus diawasi oleh pihak guru, supaya makanan tetap terjaga kebersihan dan kandungan gizinya. Makanan sehat harus mengandung zat yang diperlukan oleh tubuh, sehingga dapat membatu proses pertumbuhan dan perkembangan siswa dengan optimal. Memberantas jentik nyamuk juga harus dibiasakan pada siswa, hal ini agar mereka bisa menjaga lingkungan tetap bersih, sehingga dapat terhindar dari berbagai penyakit berbahaya. Kegiatan berantas jentik ini dilakukan untuk menghindari terjadinya penyakit demam berdarah. Kegiatan ini dapat dilakukan dengan 3M, yaitu menguras, menutup, dan mengubur tempat yang tergenang air. Kegiatan ini dilakukan minimal sekali seminggu. Apabila kegiatan ini dilakukan secara rutin disekolah, diharpkan siswa akan terbiasa dan mampu menerapkannya di lingkungan sekolah maupun di lingkungan masyarakat (Proverawati, dkk, 2012).

Sikap merupakan suatu tanggapan seseorang terhadap ransangan yang diterimanya. Sikap adalah reaksi yang masih tertutup dari seseorang dan belum mengarah pada terjadinya suatu tindakan (Notoatmodjo, 2010). Menurut Azwar (2009), sikap terdiri dari tiga komponen, yaitu kognitif, afektif, dan konatif. Kognitif adalah sesuatu hal yang dipercaya oleh suatu individu terhadap sikap yang dimilikinya. Kognitif ini lebih mengarah pada suatu masalah yang menjadi kontroversial. Afektif adalah suatu perasaan yang mengarah pada aspek emosional. Aspek emosional ini merupakan aspek yang paling kokoh terhadap perubahan yang dapat mempengaruhi dan mengubah sikap seseorang. Konatif merupakan aspek kecenderungan berperilaku tertentu sesuai dengan sikap yang dimiliki oleh seseorang yang berisi tendensi atau kecenderungan untuk bertindak atau bereaksi terhadap sesuatu dengan cara-cara tertentu. Dan berkaitan dengan obyek yang dihadapinya adalah logis untuk mengharapkan bahwa sikap seseorang adalah dicerminkan dalam bentuk tendensi.

Sikap juga mempunyai tingkatan. Tingkatan sikap tersebut terdiri dari menerima (Receiving), merespon (Responding), menghargai (Valuting), dan bertanggung jawab (Responsible). Menerima diartikan bahwa seseorang mau dan memperhatikan rangsangan yang diberikan kepadanya. Merespon yaitu memberikan tanggapan balik terhadap sesuatu yang ditanyakan, mengerjakan sesuatu dan menyelesaikan tugas yang diberikan. Menghargai yaitu mengajak orang lain untuk mengerjakan / mendiskusikan suatu masalah. Bertanggung jawab merupakan segala sesuatu yang telah dipilihnya dengan segala risiko yang akan dihadapinya. Tanggung jawab merupakan tingkatan sikap yang paling tinggi (Notoatmodjo, 2010).

Penelitian yang dilakukan oleh Febryna Diva (2013) di SDN 29 Ulak karang, didapatkan hasil bahwa sebanyak $40 \%$ siswa masih memiliki sikap yang negatif tentang PHBS. Hal ini disebabkan karena masih kurangnya fasilitas yang disediakan oleh pihak sekolah sehingga kesadaran dan pengetahuan siswa tentang PHBS itu sendiri masih kurang. Selain itu, peran dari guru sekolah juga harus di tingkatkan untuk mengawasi tingkah laku siswa, sehingga siswa lebih dapat membiasakan dan meningkatkan sikap-sikap yang positif dalam kehidupan sehari-hari.

Strategi promosi kesehatan dalam pembinaan PHBS dilakukan secara menyeluruh. Hal ini mengacu pada Piagam Ottawa (Ottawa Charter), dimana terdapat tiga strategi yang harus dilakukan pada promosi kesehatan. Strategi tersebut terdiri dari advokasi, bina suasana, dan pemberdayaan. Ketiga strategi ini dapat 
dilaksanakan dalam bentuk tindakan. Tindakan yang dilakukan adalah mengembangkan kebijakan kesehatan sebagai upaya untuk menetapkan kebijakan yang dapat memperhatikan dampaknya terhadap kesehatan masyarakat. Selanjutnya adalah menciptakan lingkungan yang mendukung, sehingga semua sector dapat melaksanakan kegiatan untuk menciptakan lingkungan yang sehat baik fisik maupun non fisik. Mengembangkan kemampuan individu dilakukan untuk mengupayakan agar individu tahu, mau dan mampu untuk memelihara dan mewujudkan kesehatannya melalui pendidikan dan pelatiah (Pedoman Pembinaan PHBS Kemenkes RI, 2011).

Perlunya memberikan pemahaman akan pentingnya berperilaku hidup bersih dan sehat diharapkan dapat merubah sikap negatif siswa. Hal ini diharapkan agar siswa mau menerima perilaku tersebut dan mau melaksanakannya dalam kehidupan sehari-hari. Untuk itu diperlukan peran guru, masyarakat sekolah lainnya, dan petugas kesehatan sebagai pendidik (educator). Petugas kesehatan diharapkan mampu bekerja sama dengan pihak sekolah, orang tua, dan masyarakat dalam mengadakan kegiatan yang dapat meningkatkan kemauan siswa untuk menerima dan mempraktekkan PHBS, salah satunya dengan mengaktifkan kegiatan UKS di sekolah. Dengan adanya UKS, diharapkan kegiatan promosi kesehatan di sekolah semakin efektif untuk membudayakan berperilaku hidup bersih dan sehat sehingga siswa dapat dan mampu menciptakan pertumbuhan dan perkembangan yang optimal (Pusat Promkes Kemenkes RI, 2011).

\section{Tindakan}

Berdasarkan tabel 5, diketahui bahwa terdapat responden yang masih belum mau melakukan PHBS di sekolah. Indikator yang paling banyak tidak dilakukan adalah jajan sehat di kantin sekolah. Semua siswa tidak jajan di kantin sekolah disebabkan karena tidak adanya fasilitas kantin di sekolah ini. Selain itu perilaku yang masih kurang dilakukan adalah pengukuran berat badan dan tinggi badan secara teratur, dan memberantas jentik nyamuk di sekolah. Hal ini disebabkan karena belum adanya jadwal yang teratur dari pihak sekolah untuk mengadakan dan melaksankan kegiatan tersebut.

Tindakan merupakan hasil penilaian terhadap rangsangan yang telah diketahui. Penilaian tersebut selanjutnya dapat di laksanakan dan di praktekkan dalam suatu bentuk tindakan. Faktor yang mendukung atau kondisi yang memungkinkan untuk terwujudnya suatu tindakan antara lain adalah karena adanya fasilitas. Tersedianya fasilitas yang mereka miliki akan berpengaruh terhadap tindakan para siswa untuk melaksanakan tindakan yang baik atau positif. Tindakan terdiri dari beberapa tingkat, yaitu presepsi, respon terpimpin, mekanisme dan adopsi (Notoatmodjo, 2010).

Desak (2009), menyatakan bahwa, faktor perilaku memiliki pengaruh sebesar 30-35\% terhadap kualitas kesehatan. Oleh karena itu diperlukan berbagai macam upaya untuk mengubah perilaku yang tidak sehat menjadi perilaku yang sehat, sehingga kehidupan sehat dan sejahtera dapat terlaksana dengan baik. Memberikan berbagai macam informasi tentang PHBS, serta memberikan contoh langsung dalam bentuk tindakan nyata, diharapkan para siswa dapat memperaktekkannya secara terus-menerus. Selain itu untuk mendukung proses tersebut diperlukan sarana dan prasarana yang memadai, sehingga perilaku hidup sehat (healthy life style) dapat dilaksanakan dalam kehidupan sehari-hari (Notoatmodjo, 2003).

Penelitian yang dilakukan oleh Febryna Diva (2013) di SDN 29 Ulak karang, diperoleh hasil bahwa sebanyak 46,7\% siswa masih bertindak kurang baik terhadap PHBS. Siswa yang masih tidak mau melakukan perilaku sehat ini dikarenakan tidak lengkapnya sarana yang disediakan oleh sekolah. Selain itu informasi yang diberikan tentang PHBS juga masih belum efektif, sehingga mereka belum memahami dengan baik manfaat melaksakan perilaku sehat.

Sekolah harus menyediakan fasilitas yang lengkap dan memenuhi syarat untuk mendukung terlaksananya kegiatan PHBS. Apabila fasilitas ini tersedia, maka siswa akan terdorong untuk melaksankan PHBS. 
Jika fasilitas sekolah tidak lengkap, maka akan mempengaruhi penerapan dan pelaksanaan Perilaku sehat oleh siswa. Siswa merasa malas melaksankan indikator PHBS karena kurangnya fasilitas yang disediakan oleh sekolah, contohnya tidak jajan di kantin sekolah (Pedoman Pembinaan PHBS Kemenkes RI, 2011).

Pembinaan PHBS disekolah pada dasarnya terdiri dari 3 proses, yaitu pemberdayaan, bina suasana, dan advokasi. Pemberdayaan dapat dilaksanakan dalam berbagai cara, seperti pemberian proses belajar dan mengajar, dalam kegiatan diluar proses belajar dan mengajar, dan juga dapat dilakukan melalui penyelenggaraan klinik konsultasi kesehatan yang dikelola oleh sekolah dan bekerjasama dengan petugas kesehatan. Bina suasana dapat dilakukan oleh semua masyarakat sekolah seperti pemuka masyarakat, pengurus organisasi anak didik, pengurus pramuka, dan sebaginya, sehingga mereka dapat menjadi panutan dalam pelaksanaan PHBS di lingkungan sekolah. Bina suasana ini juga dapat dilaksanakan dengan memanfaatkan media yang ada, seperti pembuatan majalah dinding (madding), poster, serta penyelenggaraan seminar mengenai kesehatan dan perilaku sehat. Sedangkan advokasi dilakukan oleh fasilitator yang berasal dari kabupaten, kota, atau provinsi terhadap pihak sekolah, sehingga pihak sekolah berperan aktif dalam menunjang kegiaatan pembinaan PHBS di sekolah (Pedoman Pembinaan PHBS Kemenkes RI, 2011).

Anak usia sekolah sangat peka terhadap stimulus yang diberikan. Oleh sebab itu anak usia ini mudah untuk dibimbing, diarahkan, dan ditanamkan kebiasaan untuk berperilaku hidup bersih dan sehat. Untuk itu sangat diperlukan peran serta dari berbagai pihak baik itu orang tua, guru, tenaga kesehatan, komite sekolah dan masyarakat.

Siswa sekolah pada hakekatnya merupakan kelompok usia yang paling mudah dan cepat untuk menerima perubahan yang diberikan. Diharapkan dengan pemberian pemahaman tentang hidup bersih dan sehat pada anak sekolah ini dapat menimbulkan kebiasaan yang positif untuk memelihara dan meningkatkan kesehatan, budaya hidup bersih dan sehat akan terbawa sampai besar dan pada saat dewasa budaya tersebut tidak akan berubah lagi (Maryunani, 2013).

Masa anak-anak ini sangat tepat untuk menanamkan nilai-nilai positif dan kesehatan, sehingga dapat terbiasa dan terbawa sampai usia dewasa nantinya. Anak belajar langsung dari lingkungannya mengenai bagaimana ia harus bertingkah laku untuk meningkatkan kualitas hidupnya dan mampu memperoleh derajat kesehatan yang setinggi-tinnginya.

Diawali dengan memberikan pengertian tentang PHBS dan dilanjutkan dengan halhal mengenai kesehatan lainnya, maka diharapkan akan tumbuh minat dan kemauan dari siswa untuk ikut dan aktif dalam menerapkan program PHBS di sekolahnya maupun di tempat tinggalnya. Apabila hal ini terlaksana, maka tujuan yang diharapkan akan tercapai dan pengetahuan siswa tentang PHBS akan lebih meningkat.

\section{SIMPULAN}

Berdasarkan hasil penelitian terhadap pengetahuan siswa tentang PHBS di SDN 42 Korong Gadang, maka dapat ditarik kesimpulan, bahwa masih terdapat siswa yang berpengetahuan rendah tentang indikator PHBS di sekolah, terutama pada penggunaan jamban bersih dan sehat. Penelitian ini juga menjelaskan bahwa siswa masih ada yang belum mau bersikap menerima dan tidak melaksanakan jajan sehat di kantin sekolah. Hal ini disebabkan karena tidak adanya fasilitas kantin di sekolah ini.

\section{SARAN}

Bagi pihak sekolah diharapkan agar para guru lebih meningkatkan peran aktifnya untuk menjelaskan penerapan perilaku sehat pada siswanya dan mengaktifkan program UKS sehingga siswa dapat meningkatkan dan mempraktekkan perilaku hidup bersih dan sehat secara optimal. Selain itu, sekolah juga harus melengkapi fasilitas untuk mendukung terlaksananya PHBS dengan baik dalam kehidupan sehari-sehari. 
Bagi pihak tenaga kesehatan untuk dapat memberikan penyuluhan kesehatan yang rutin mengenai PHBS (pengertian PHBS dan indikator PHBS di sekolah) secara rutin dan terjadwal.

Bagi peneliti selanjtnya Diharapkan untuk dapat melakukan penelitian tentang variabel, cara ukur dan tingkat analis yang berbeda, seperti analisis hubungan dan faktor-faktor yang mempengaruhi perilaku siswa terhadap PHBS.

\section{DAFTAR PUSTAKA}

Azwar. 2009. Sikap Manusia Teori dan Pengukurannya.Yogyakarta : Pustaka Pelajar

Departemen Kesehatan, RI. 2008. Riset Kesehatan Dasar (RISKESDAS 2007). Jakarta : Departemen Kesehatan

Departemen Kesehatan, RI. 2013. Riset Kesehatan Dasar (RISKESDAS 2013). Jakarta : Departemen Kesehatan

Depkes RI. 2010.Perilaku Hidup Bersih dan Sehat di Rumah Tangga.Jakarta: Departemen kesehatan

Depkes RI. 2010.Menkes Himbau Terapkan PHBS di Sekolah. Majalah Promkes

Dewi N. 2012.Gizi Anak Sekolah. Jakarta: PT. Kompas Media Nusantara

Desak, M.D. 2009.Analisis Kebutuhan Dalam Pengembangan Buklet Edukatif Temati (Bet) Untuk Pendidikan Kesehatan Di SD.Bali.Universitas Pendidikan Ganesha

Dinas Kesehatan Kota Padang. 2012. Laporan Dinas kesehatan Kota Padang

Diva, F. 2013. Gambaran Perilaku Hidup Bersih Dan Sehat Siswa SDN 29 Ulak Karang Padang Tahun 2013.Padang. Politeknik Kemenkes Padang

Hidayat, A. Aziz Alimu1.2009.Metode Penelitian dan Teknik Analisis Data. Jakarta:Salemba Medika

Kementerian Kesehatan RI. 2011. Pedoman Pembinaan Perilaku Hidup Bersih dan Sehat (PHBS).Jakarta.Peraturan Menteri Kesehatan

Lubis, Z. S. A. Pengaruh Penyuluhan Dengan Metode Ceramah Dan Diskusi Terhadap Peningkatan Pengetahuan Dan Sikap Anak Tentang PHBS Di Sekolah Dasar Negeri 065014 Kelurahan Namogajah
Kecamatan Medan Tuntungan Tahun 2013.Medan. Universitas Sumatera Utara

Marlina, R. L. 2011. Analisis Manajemen Promosi Kesehatan Dalam Penerapan Perilaku Hidup Bersih dan Sehat (PHBS) Tatanan Rumah Tangga di Kota Padang Tahun 2011.Padang. Universitas andalas

Maryunani, A. 2013.Perilaku Hidup Bersih dan Sehat.Jakarta:CV Trans Info Media

Mulyadi.2014. Tingkat Pengetahuan Siswa Terhadap Penerapan Perilaku Hidup Bersih Dan Sehat(PHBS) di SDN 197 Palembang Tahun 2014.STIK Bina Husada. Palembang

Notoatmodjo, S. 2003.Pendidikan dan Perilaku Kesehatan.Jakarta: Rineka Cipta

Notoatmodjo, S. 2010. Ilmu Perilaku Kesehatan. Jakarta: Rineka Cipta

Notoatmodjo, S. 2012. Metodologi Penelitian Kesehatan. Jakarta: Rineka Cipta

Nursalam.2008. Konsep dan penerapan metodologi penelitian keperawatan. Jakarta: EGC

Pusat Promkes Departemen Kesehatan RI. 2011. Interaksi Suplemen PHBS di Sekolah. Jakarta

Pusat Promkes Departemen Kesehatan RI.2011. Lembar Balik Aku Sehat Sekolahku Sehat Prestasiku Meningkat. Jakarta

Proverawati, dkk.2012. Perilaku Hidup Bersih dan Sehat.Yogyakarta

Sumijatun, dkk.2006. Konsep Dasar keperawatan Komunitas.Jakarta:EGC

Syukriyah, E. 2011. Gambaran Pengetahuan, Sikap dan Tindakan Murid SD Tentang PHBS di SDN 06 Lubuk Layang.Padang: Poletkkes Kemenkes Padang

Utami, N. M. S. 2009. "Hubungan Pelaksanaan Program UKS dengan PHBS Anak Usia Sekolah Kelas IV dan V di SDN Pangkalan Jati Limo Kodya Depok. Jakarta.UPN

Zaviera, F. 2008.Mengenali dan Memahami Tumbuh Kembang Anak.Yokyakarta: KATAHATI 